\title{
Effect of thermo-hydro-mechanical densification on microstructure and properties of poplar wood (Populus tomentosa)
}

\author{
Minzhen Bao ${ }^{1,2} \cdot$ Xianai Huang ${ }^{3} \cdot$ Mingliang Jiang $^{1} \cdot$ Wenji Yu ${ }^{1} \cdot$ Yanglun $\mathbf{Y u}^{1}$
}

Received: 20 February 2017/ Accepted: 30 June 2017/Published online: 6 September 2017

(C) The Japan Wood Research Society 2017

\begin{abstract}
This study aimed at developing a thermo-hydromechanical (THM) processing to compress poplar wood and investigating the effects of high temperature, moisture, and pressure during the THM processing on the changes in microstructure, porosity, mechanical properties, and dimensional stability of compressed poplar wood. The variations in these properties were correlated and their mathematical relations were determined. Poplar woods with high moisture content were compressed using different pressures at a temperature of $160{ }^{\circ} \mathrm{C}$ for different periods. The compression level was characterized by the volume compression ratio (CR), which is defined as the ratio of the compression volume and the original volume of sample before and after THM processing. The obtained results indicated that the high pressure of THM process caused the collapsing of wood cell lumens and the developing of a certain amount of fractures in the cell wall. The damage level of wood cells increased with increasing pressure and time. Moreover, the pressure narrowed the cell lumens, which decreased significantly the pore volume
\end{abstract}

Wenji Yu

yuwenji@caf.ac.cn

Yanglun Yu

yuyanglun@caf.ac.cn

1 Key Laboratory of Wood Science and Technology of State Forestry Administration, Research Institute of Wood Industry, Chinese Academy of Forestry, Xiang Shan Road, Hai Dian District, Beijing 10091, People's Republic of China

2 China National Bamboo Research Center, Key Laboratory of High Efficient Processing of Bamboo of Zhejiang Province, Wen Yi Road 310, Hangzhou 310012, People's Republic of China

3 CanmetEnergy, Ottawa, Natural Recourse Canada, 1 Haneel Dr, Nepean, Ottawa K1A 1M1, Canada in wood substrate. The pore size distribution shifted from the level of macropores to those of mesopores and micropores after THM process. The THM process created superior mechanical property, especially for those with higher CR. Besides, it was revealed that the process decreased dramatically the set recovery of treated woods and improved their dimensional stability. A significant improvement was achieved in terms of the mechanical and physical properties of compressed poplar wood via the structural reformation during the THM process.

Keywords Thermo-hydro-mechanical process .

Microstructure $\cdot$ Porosity $\cdot$ Bending property $\cdot$ Dimensional stability

\section{Introduction}

Wood is a natural renewable resource that presents numerous advantages, such as high ratio of strength to weight, renewability, processability, and biocompatibility. With unceasing consumption of high-quality wood and stricter environmental regulations, fast-growing wood is expected to be used in wood-based materials because of its ease of reproduction. Poplar wood is one of the most popular fast-growing tree species planted in a large scale in China, with a plantation area of 9.97 million $\mathrm{hm}^{2}$ [1]. Poplar is generally used in producing wood-based composites such as high-density particle board [2], high-density laminated veneer lumber [3], compressed wood [4], and scrimber [5]. However, the natural defects of poplar with thin cell walls, large cell cavity, and short fibers contribute to its low-density, large porosity, and low mechanical strength. To improve the competitiveness of wood-based products made from poplar wood to substitute for high- 
quality hardwoods, many attempts have been made to develop a suitable process, such as compressing the wood $[6,7]$, impregnating the void volume with a fluid substance [8], and a combination of compression and impregnation [4]. Nevertheless, their use is restricted to the lack of the dimensional stability, the complexity of densification, and the damage to the environment.

There is a renewed interest in producing sustainable wood-based materials by subjecting solid wood to the effects of temperature, moisture, and mechanical action, also called thermo-hydro-mechanical (THM) process. THM process is one of the processes for manufacturing wood-based panels and an efficient way to improve the natural properties and produce stable materials $[9,10]$. The heat treatment can improve resistance to decay [11], decrease hygroscopicity [12], and improve dimensional stability [13]. The moisture induces a mechano-sorption effect and further softens the wood. This enables mechanical compression of wood without cell wall fracture. Poplar wood with poorer mechanical properties can be used in new high-performance wood-based composite products if they are treated with heat and steam [14]. Due to the hydrothermal modification, the obtained composite materials after compression have a higher density [15], excellent mechanical properties [16], and improved biological durability $[17,18]$.

The THM process is a usual densification process vastly studied in the literature. However, to the best of our knowledge, the modification of solid wood with high moisture with heat and pressure in an open system was less studied and less spread. Moreover, there are not lots of studies regarding the THM wood at fixed high temperature with elevated pressures for a short time. The morphology of wood can be varied significantly and the void volume can be drastically decreased in the higher degree of densification. The densification level in most previous studies had relatively lower CR (below 50\%). Excessive compression can easily crush the wood cells; consequently, the yields of final product and its mechanical properties become low. So, it is important to study the influence of THM process on the microstructure and properties of poplar with extremely high CR (above $50 \%)$.

The objective of this study was to investigate the effect of THM processing with excessive compression on the deformation of wood cell structure, as well as the physical and mechanical properties of treated poplar wood with the CR above $50 \%$. Due to alteration of the cell wall of wood during the THM processing, the porosity or cell wall density alters and the pore size distribution changes. Based on the fact, the cell morphology and porosity of THM wood in relation to the CR were characterized by scanning electron microscopy
(SEM) and mercury intrusion porosimetry (MIP). The narrowed cell cavity and changed cell wall generated by THM processing can also lead to mechanical strength, liquid permeability, and dimensional stability. The mechanical properties, set recovery (SR) as well as water absorption (WA) of THM wood were also examined.

\section{Materials and methods}

\section{Materials}

The 15-year-old fast-growing poplar (Populus tomentosa) with the diameter of $220 \mathrm{~mm}$ at the breast height was obtained from a fast-growing wood plantation located in Shandong, China. The air-dried density of the wood samples was determined as $0.39 \mathrm{~g} / \mathrm{cm}^{3}$. The samples from the same growth increment of annual ring in the tree stem were prepared with the nominal sizes of $250 \times 100 \times 30 \mathrm{~mm}$ (longitudinal $\times$ tangential $\times$ radial).

\section{THM process}

The processing parameters and procedures are shown in Table 1 and Fig. 1. First, all the specimens were oven dried to release the growth stress and minimize the effects of specimen variation and then fully water-saturated. Next, all samples before THM process were controlled to reach a final moisture content of $25 \pm 1 \%$ and pre-heated with temperature of metal plate surface at $160{ }^{\circ} \mathrm{C}$ (according to preliminary experiments) for $10 \mathrm{~min}$. In our previous experiments, three temperatures of 140,160 and $180{ }^{\circ} \mathrm{C}$ were chosen for heat treatment. With $140{ }^{\circ} \mathrm{C}$, the desired results could not be achieved. The solid wood can be compressed into THM wood with CR75 effectively at the temperatures of 160 and $180{ }^{\circ} \mathrm{C}$. However, significant decrease in the mechanical properties of THM wood at temperatures of $180{ }^{\circ} \mathrm{C}$ was found. Sometimes, the CR75 wood was burst during THM process at $180{ }^{\circ} \mathrm{C}$. Therefore, $180{ }^{\circ} \mathrm{C}$ may be the maximum temperature practical for wood THM processing to obtain high-CR wood. Therefore, the lower temperature of $160{ }^{\circ} \mathrm{C}$ was chosen to ensure the quality and property of THM wood.

Then, specimens were compressed from initial thickness (30 mm) to four target thicknesses $(15,12,9$, and $7.5 \mathrm{~mm})$ with a special mold to maintain the dimensions, providing four different volume CRs. The symbols CR50, CR60, CR70, and CR75 in Table 1 mean the compression ratios of 50,60, 70 and $75 \%$, respectively. Finally, the samples were annealed at a constant temperature of $160^{\circ} \mathrm{C}$ for $20 \mathrm{~min}$ and then cooled down to $50{ }^{\circ} \mathrm{C}$ with the set pressures. Eight replicates were carried out for each group. For 
Table 1 Conditions and parameters of THM process

\begin{tabular}{|c|c|c|c|c|c|}
\hline \multirow[t]{2}{*}{ Process steps } & \multirow[t]{2}{*}{ Parameters } & \multicolumn{4}{|c|}{ Treatment samples } \\
\hline & & CR50 & CR60 & CR70 & CR75 \\
\hline \multirow[t]{3}{*}{ Pre-heating } & Temperature $\left({ }^{\circ} \mathrm{C}\right)$ & 160 & 160 & 160 & 160 \\
\hline & Pressure (MPa) & 0 & 0 & 0 & 0 \\
\hline & Duration (min) & 10 & 10 & 10 & 10 \\
\hline \multirow[t]{3}{*}{ Compressing } & Temperature $\left({ }^{\circ} \mathrm{C}\right)$ & 160 & 160 & 160 & 160 \\
\hline & Maximum pressure $(\mathrm{MPa})$ & 4 & 5.5 & 8 & 12 \\
\hline & Duration (min) & 8 & 10 & 12 & 14 \\
\hline \multirow[t]{3}{*}{ Annealing } & Temperature $\left({ }^{\circ} \mathrm{C}\right)$ & 160 & 160 & 160 & 160 \\
\hline & Pressure (MPa) & 4 & 5.5 & 8 & 12 \\
\hline & Duration (min) & 20 & 20 & 20 & 20 \\
\hline \multirow[t]{3}{*}{ Cooling } & Temperature $\left({ }^{\circ} \mathrm{C}\right)$ & 50 & 50 & 50 & 50 \\
\hline & Pressure (MPa) & 4 & 5.5 & 8 & 12 \\
\hline & Duration (min) & 15 & 15 & 15 & 15 \\
\hline
\end{tabular}

$T H M$ thermo-hydro-mechanical, $C R$ compression ratio

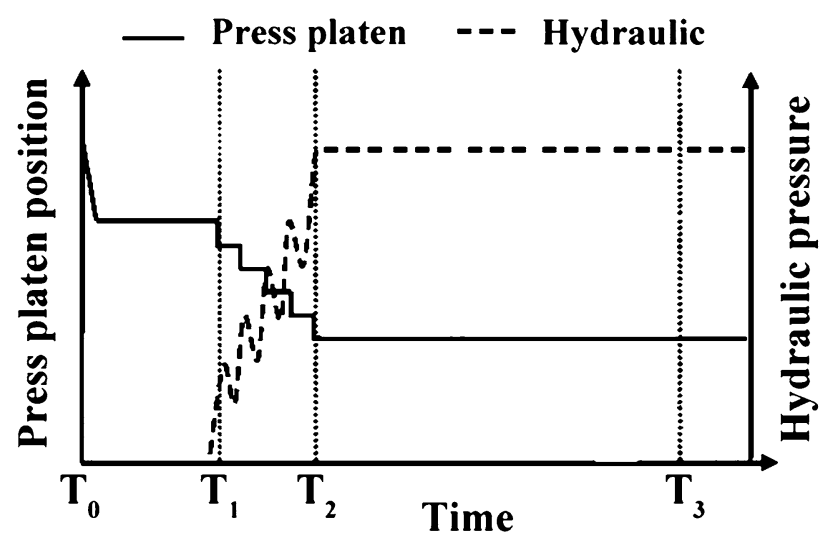

Fig. 1 Schematic diagram of the THM process: pre-heating $\left(T_{0}-T_{1}\right)$, compression $\left(T_{1}-T_{2}\right)$, and annealing $\left(T_{2}-T_{3}\right)$. Total treatment duration was approximately $40 \mathrm{~min}$

comparison, the untreated control poplar samples were prepared as well. Before property characterization, all specimens were stored in a conditioning chamber at $20^{\circ} \mathrm{C}$ and a relative humidity of $65 \%$ until they reached constant mass weights.

\section{Scanning electron microscopy (SEM)}

SEM analysis was used to investigate the microscopic structural changes occurring in THM woods. Cross sections of specimens were mounted on conductive adhesives, sputter coated with platinum, and observed under SEM (Hitachi S-4800, Japan) at $10 \mathrm{kV}$ voltages. Several images at $2000 \times$ were obtained for each group of the specimens. The effect of water soaking on the changes in microstructure was also examined on the same samples after water soaking.

\section{Mercury intrusion porosimetry (MIP)}

The samples with a dimension of $20 \times 10 \times 6 \mathrm{~mm}$ on the radial, tangential, and transverse sections were cut from the untreated wood and THM-treated woods. The porosity and pore size of all samples were measured and characterized by an Autopore IV Automated Mercury Porosimeter (Micromeritics Instrument Corp., USA). The relation between pressure and pore diameter was described by the Washburn equation:

$r=-\frac{2 \gamma \cos \theta}{p}$

where $r$ is the pore radius, $p$ is pressure, $\gamma$ is the surface tension of mercury $(0.48 \mathrm{~N} / \mathrm{m})$, and $\theta$ is the wetting angle of mercury $\left(141^{\circ}\right)[19,20]$. Measurements of total intrusion volume, total pore surface area, pore size, and distribution were all feasible. The porosity determined with MIP method referred to the percentage of open pores that were $\mathrm{Hg}$ accessible, while the theoretical porosity included all open and closed pores. The theoretical porosity can be calculated according to the following equation:

$C(\%)=100 \times\left(1-\rho / \rho_{\mathrm{s}}\right)$,

where $C$ is the theoretical porosity, $\rho$ is bulk density and $\rho_{\mathrm{s}}$ is the specific solid density which is assumed as $1.50 \mathrm{~g} / \mathrm{cm}^{3}$ according to the literature [21]. The theoretical porosity $C$ was determined and compared with the porosity measured by MIP method.

\section{Three-point bending test}

The air-dried specimens for three-point bending test were prepared with the size of $250 \times 20 \mathrm{~mm}$ in the longitudinal 
and width directions. The modulus of rupture (MOR) and modulus of elasticity (MOE) in static bending were measured based on GB/T 1936.1-2009 [22]. All measurements were performed on 6 specimens.

\section{Correlation between bending property and density}

CR was an indicator of density: the lower the CR, the higher the density. Many researchers [23, 24] had reported about relations between mechanical property $(m)$ and density $(\rho)$. The empirical model describing the relationship between strength and density was used to evaluate possible detrimental effects caused by THM process. For untreated wood, the relation between $m$ and $\rho$ had been reported [25] as shown in the following equation:

$\ln m=\ln a+b \cdot \ln \rho$,

where $\ln a$ and $b$ are the constants in bending property.

The general model [26] was used to describe the relation between $m$ and $\rho$ of THM wood, described as follows:

$\ln m=\ln a+d_{\mathrm{d}} \cdot \ln a_{\mathrm{d}}+b \cdot \ln \rho+d_{\mathrm{d}} \cdot b_{\mathrm{d}} \cdot \ln \rho+\varepsilon$,

where $\ln a$ and $b$ are the intercepts and power for untreated wood. $\ln a_{\mathrm{d}}$ and $b_{\mathrm{d}}$ are the differences in intercepts and power between untreated and THM wood, the dummy variable $d_{\mathrm{d}}$ took the value 0 for untreated wood and 1 for THM wood. $\varepsilon$ is the random error.

\section{Water soaking test for evaluating set recovery, water absorption, and dimensional stability}

SR, WA, and swelling tests were performed for the THM samples with size $20 \mathrm{~mm} \times 20 \mathrm{~mm} \times$ sample thickness according to the standard GB 1934.2-2009 [27]. The thickness and weights of all the untreated and THM samples were measured. The samples were soaked in water for 30 min with vacuum pressure of $0.1 \mathrm{MPa}$, followed by $360 \mathrm{~min}$ at atmospheric pressure, then placed in boiling water for $30 \mathrm{~min}$, and finally were oven dried. The dimension and weight of samples at saturated condition and oven-dried condition were recorded. The SR was calculated as follows:

$\mathrm{SR}(\%)=\frac{T_{\mathrm{R}}-T_{\mathrm{C}}}{T_{0}-T_{\mathrm{C}}} \times 100$,

where $T_{\mathrm{R}}$ is oven-dry thickness after soaking $(\mathrm{mm}), T_{\mathrm{C}}$ is compressed thickness after THM process $(\mathrm{mm})$, and $T_{0}$ is initial uncompressed thickness $(30 \mathrm{~mm})$.

WA was evaluated according to the below equation:

$\mathrm{WA}(\%)=\frac{W_{\mathrm{i}}-W_{\mathrm{e}}}{W_{\mathrm{e}}} \times 100$, where $W_{\mathrm{i}}$ is weight after immersion in water for $390 \mathrm{~min}$ (g) and $W_{\mathrm{e}}$ is equilibrium weight before immersion in water (g).

Width and thickness swellings were also determined by measuring dimensions of the specimens using the below equation:

Width or thickness swelling $(\%)=\frac{L_{1}-L_{0}}{L_{0}} \times 100$,

where $L_{1}$ is saturation dimension (width or thickness) after water soaking $(\mathrm{mm})$ and $L_{0}$ is dimension before immersion in water. For each THM treatment, the tests were performed on 8 specimens.

\section{Statistical analysis}

One-way analysis of variance (ANOVA) was conducted to study the effect of THM process on the properties of the poplar wood at the 0.05 significance level $(P<0.05)$. All the statistical analyses were performed using the software of IBM SPSS Statistics 22.

\section{Results and discussion}

\section{Microstructure of THM wood}

Figure 2 presents the SEM images on the transverse surfaces of untreated and THM woods. Figure $2 \mathrm{a}$ shows that the untreated poplar has thick-walled wood fibers and cell lumen with diameter of 8-20 $\mu \mathrm{m}$. From comparisons in the microstructure between the untreated wood and THM woods shown in Fig. 2, the pore volume of the THM wood originated from vessels and fiber cells due to THM process became smaller or disappeared. This would produce lower porosity, which could be confirmed by MIP analysis (see Table 2). As apparent from Fig. 2b, c, it showed that the compression levels of CR50 and CR60 caused a large deformation to the pores. Fibers collapsed and flattened in the direction of the compression. The pores in THM wood with CR50 became oval or irregular and the intercellular layer slid due to compression. Certain fiber cells of CR60 THM wood were compressed and left small volume. There were cells that still maintained irregular cell lumen but with smaller volume than those of CR50 wood as shown in Fig. 2c. Since the structural differences between earlywood and latewood for poplar wood are minor, it was difficult to distinguish the differences in morphology between them after THM process. The high pressure in the THM process drastically reduced the volume of void spaces in the wood by compressing the cell lumens. Most of the cells in CR70 
Fig. 2 SEM images $(\times 2000)$ on transverse surface of untreated wood and THM wood samples: a untreated, b CR50, c CR60, d CR70, e CR75. The fractures in the fiber cell walls are shown with white arrows
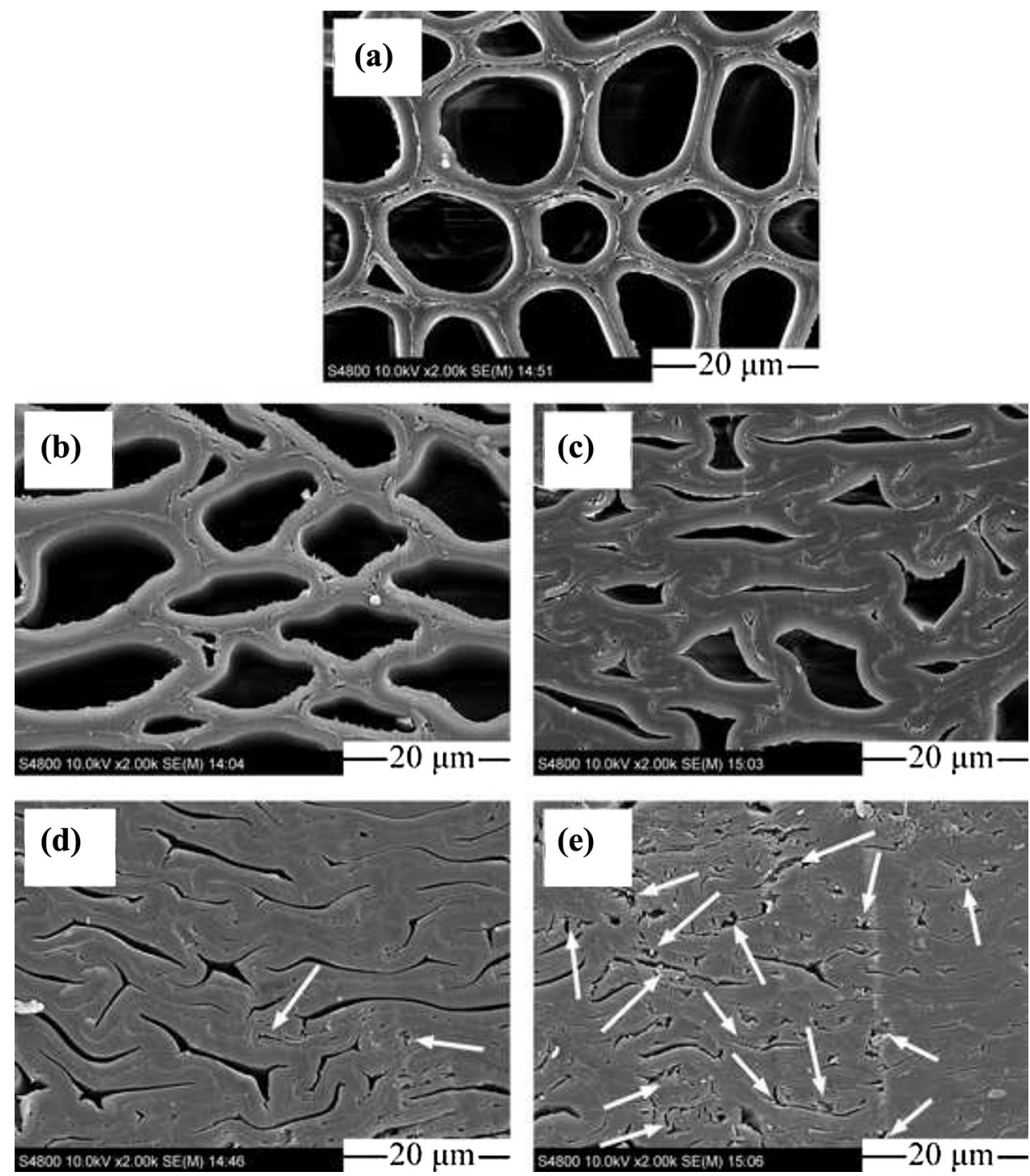

Table 2 The pore characteristic parameters of untreated wood and THM woods from MIP

\begin{tabular}{|c|c|c|c|c|c|c|c|}
\hline Samples & $\begin{array}{l}\text { Oven density } \\
\left(\mathrm{g} / \mathrm{cm}^{3}\right)\end{array}$ & $\begin{array}{l}\text { Bulk density at } \\
2.90 \mathrm{kPa}\end{array}$ & $\begin{array}{l}\text { Total intrusion } \\
\text { volume }(\mathrm{mL} / \mathrm{g})\end{array}$ & $\begin{array}{l}\text { Total pore } \\
\text { area }\left(\mathrm{m}^{2} / \mathrm{g}\right)\end{array}$ & $\begin{array}{l}\text { Average pore diameter } \\
(4 \mathrm{~V} / \mathrm{A}) / \mathrm{nm}\end{array}$ & $\begin{array}{l}\text { MIP } \\
\text { porosity } \\
(\%)\end{array}$ & $\begin{array}{l}\text { Theoretical } \\
\text { porosity }(\%)\end{array}$ \\
\hline Untreated & 0.41 & 0.43 & 0.90 & 40.80 & 90.6 & 49.03 & 73.20 \\
\hline CR50 & 0.75 & 0.75 & 0.65 & 33.24 & 88.5 & 48.07 & 50.98 \\
\hline CR60 & 0.90 & 0.97 & 0.34 & 28.85 & 40.5 & 32.79 & 41.18 \\
\hline CR70 & 1.10 & 1.10 & 0.19 & 19.04 & 38.8 & 20.26 & 28.10 \\
\hline CR75 & 1.30 & 1.41 & 0.04 & 11.56 & 12.3 & 5.00 & 15.03 \\
\hline
\end{tabular}

THM thermo-hydro-mechanical, $C R$ compression ratio, V/A volume/area, MIP mercury intrusion porosimetry

THM wood appeared to be deformed with little damage in cell wall. Furthermore, the lumen in the fiber cells, especially the corner of cell lumen, has been partly compacted. A few fractures in the fiber cell walls took place when the
CR reached $75 \%$ (see arrows in Fig. 2e). The existence of cracks in wood fiber wall indicated that the fiber cell wall seemed to be turned brittle by a combination of the temperature, moisture, and stress, which led to a marked 
destruction of cell structure. Fortunately, this deformation of wood cell occurred in the transverse direction, which results in less influence on the mechanical properties of THM wood. The results from above analysis implied that the THM process changes significantly the structure of wood, especially with higher CR.

\section{Pore characteristic of THM wood}

Using the MIP, the values of bulk density at $2.90 \mathrm{kPa}$, total intrusion volume, total pore area, average pore diameter [4 volume/area (V/A)], and porosity were measured and are shown in Table 2. The theoretical porosities were calculated using Eq. (2) and are also presented in Table 2.

It can be observed from Table 2 that the values of oven density and bulk density at $2.90 \mathrm{kPa}$ increased with increasing $\mathrm{CR}$, while the total intrusion volume, total pore area, average pore diameter, and porosity of THM woods showed the opposite trend and were lower than the corresponding values of untreated wood. The measured porosities were also smaller than the calculated theoretical porosities for all samples due to the closure and non-connection of wood cells. Logically, higher total pore area is related to higher porosity. The THM wood with CR75 had a minimum total pore area of $11.56 \mathrm{~m}^{2} / \mathrm{g}$ and a smallest porosity of $5.00 \%$. The total pore area indicated that the total of micro-voids for CR75 were more than that for CR50. These values supported the observed changes in cell structure after THM treatment as shown in Fig. 2. Table 2 also indicated that the pore diameter could be controlled by controlling the CR during the THM process. From the analysis of Table 2, the THM process resulted in a significant decrease in all the pore characteristic parameters. The increased density and reduced porosity confirmed that cell cavity volume was compressed and cell walls became closer for THM wood with higher CR. The total pore area and average pore diameter of THM woods were smaller than those of the untreated wood, implying the loss in porosity as summarized in Table 2 . These results were in agreement with the results reported in previous publications [28, 29].

Wood is a porous material [30]. The pores in the wood can be divided into three categories according to the IUPAC classification [31], namely macropores (pore size $>50 \mathrm{~nm})$, mesopores $(2 \mathrm{~nm}<$ pore size $<50 \mathrm{~nm})$, and micropores (pore size $<2 \mathrm{~nm}$ ). The sizes of pores in different structures of hardwoods are presented in Table 3 . Poplar wood possesses a high ratio of macropores owing to the occurrence of vessels and wood fibers with volume percentages of 90-96\%, with diameters ranging from 15 to $250 \mu \mathrm{m}$. The range of the mesopores complies with the apertures of pores in cell with an average diameter of $2-50 \mathrm{~nm}$. The amount of micropores is low and can be accounted for by the submicroscopic pore system within the cell wall. The morphology varied significantly and the void volume of the wood drastically decreased depending on the degree of compression. Therefore, the pore parameters can be changed significantly under the THM process.

Figure 3 shows the cumulative pore volume, pore area, log-differential pore volume, and intrusion volume percentage as a function of pore diameter for untreated wood and THM woods. As could be seen in Fig. 3a, c, the dominant pore radius with the main contribution to cumulative pore volume for untreated wood was from $32 \mathrm{~nm}$ to $80 \mu \mathrm{m}$, while the THM woods was from $10 \mathrm{~nm}$ to $10 \mu \mathrm{m}$. The decreasing rate of the cumulative pore volume with the increasing pore diameter of the untreated wood was faster than those of THM woods. At the same pore diameter, the cumulative pore volume decreased when the CR increased, which was in agreement with the result in Table 2. Different CR showed the same trend but with different slopes. The cumulative pore volume of CR75 did not change significantly with pore diameter and the value approached to zero. This is obviously a consequence of compression on cell lumen and cell wall due to the high thermal stress, which can also be confirmed by the porosity results measured using gas pycnometry by Zauer et al. [36].

As apparent in Fig. 3b, the pore diameter ranging from 10 to $100 \mathrm{~nm}$ played a decisive role for cumulative pore area in untreated wood, while the pore diameter ranging from 3 to $50 \mathrm{~nm}$ played a main role for cumulative pore area in THM woods. Especially in CR75 THM wood, this range reduced to $3-10 \mathrm{~nm}$. For untreated wood, the cumulative pore area of $10-100 \mathrm{~nm}$ pores accounted for one half of total cumulative pore area as a result of numbers of vessel pits and pores in cell wall. The pores with the size of 3-10 nm were mainly pits, voids between compressed vessel and fiber cell walls, and micro-voids in the cell wall in CR75 THM wood. The increase in the microsize pores indicated that the connectivity between cells was deteriorated and created micropores after the THM process.

Figure $3 \mathrm{c}$ displays the pore volume calculated using the logarithm of the differential pore diameters. The log-differential distribution curves of untreated wood and THM wood with CR50 showed a multimodal characteristic, while the THM woods with CRs above $60 \%$ only had a unimodal feature. The peak values obtained at pore diameters such as $32.4,3492.8$, and $8056.2 \mathrm{~nm}$ for the untreated wood and $284.2 \mathrm{~nm}$ for THM wood with CR50 indicated the inflection point of pore volume change. For untreated wood, the segment of the curve with the high slope corresponding to the pore sizes of $8506.2 \mathrm{~nm}$ might reflect the vessels. The peaks obtained at about 3492.8 and $32.4 \mathrm{~nm}$ reflected the lumens of tracheids or libriform fibers and the pointed ends of the fibers [20]. In THM wood with CR50, 
Table 3 Pore dimensions and shapes of different structures in hardwoods

\begin{tabular}{llll}
\hline Pore types & Diameter & Pore shape & References \\
\hline Macro & & & \\
Resin canal & $50-300 \mu \mathrm{m}$ & Cylindrical & {$[32]$} \\
Vessel lumen & $20-400 \mu \mathrm{m}$ & Cylindrical & {$[33]$} \\
Tracheid lumen & $20-30 \mu \mathrm{m}$ & Irregular cylindrical & {$[33]$} \\
Fiber lumen & $\sim 15 \mu \mathrm{m}$ & Cylindrical & {$[33]$} \\
Macro/meso/micro & & & \\
Pores in cell wall & $1-100 \mathrm{~nm}$ & Slit-shaped & {$[32]$} \\
Microfibril clearance & $2-4.5 \mathrm{~nm}$ & Slit-shaped & {$[32]$} \\
Micro & & & {$[34,35]$} \\
Lignin & $0.3-0.6 \mathrm{~nm}$ & Slit-shaped &
\end{tabular}

(a)

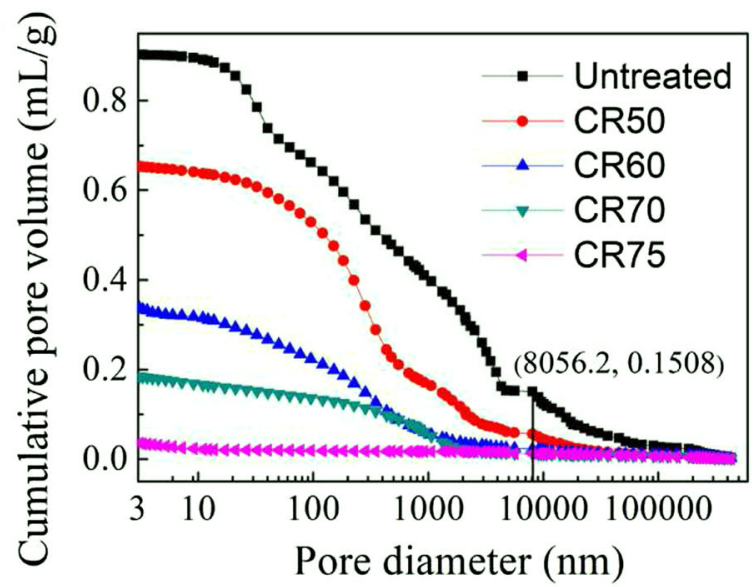

(c)

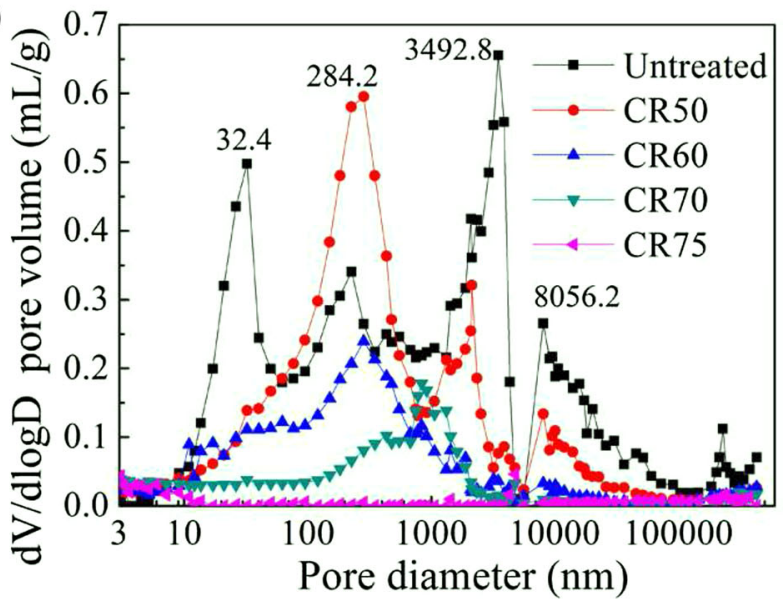

(b)

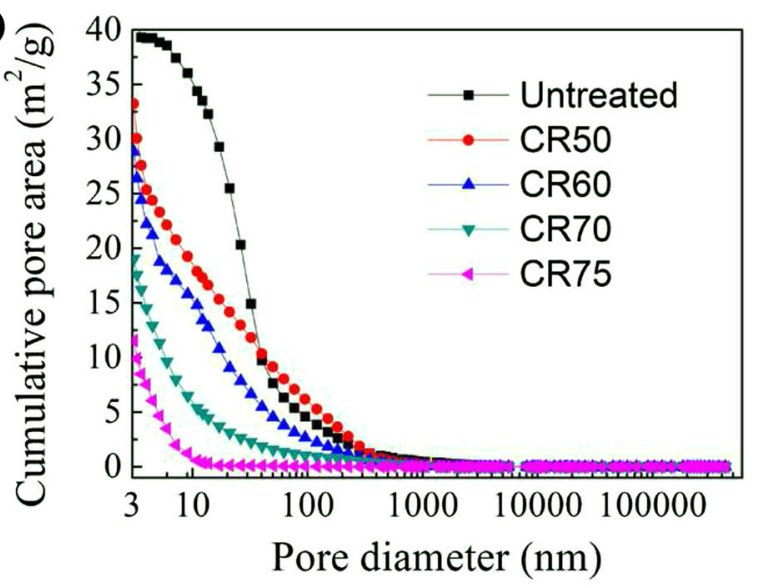

(d)

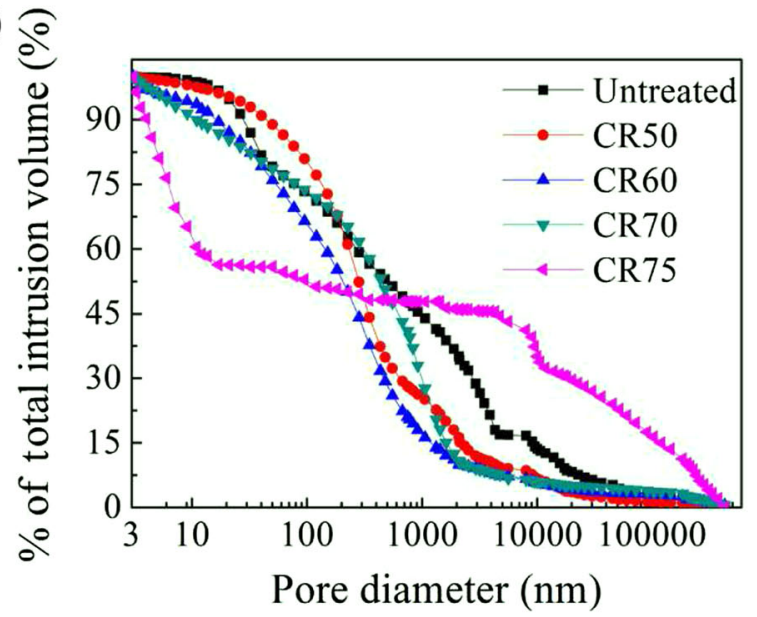

Fig. 3 Pore characteristic of untreated wood and THM woods. a Cumulative pore volume versus pore diameter; b cumulative pore area versus pore diameter; c log-differential intrusion versus pore diameter; d percentage of total intrusion volume versus pore diameter

the peak obtained at about $284.2 \mathrm{~nm}$ showed that the cumulative pore volume had reached the high value and stabilized basically. It is obvious that the proportion of fibers and tracheids was higher than that of vessels (shown in Fig. 2). These pore diameters corresponded to the pointed ends of the tracheids and the pit chambers present significantly in the vessel walls [19]. The pore diameter moved towards shorter direction due to the THM process indicating that the THM process changed significantly the volume and pore size distribution. The peak at $8056.2 \mathrm{~nm}$ and $3.5 \mu \mathrm{m}$ reduced and then disappeared when $\mathrm{CR}$ increased. This confirmed the volume contributed by the vessel and fiber lumens was reduced or removed by the pressure during THM process. 
Figure $3 \mathrm{~d}$ shows that $68 \%$ of untreated poplar wood pores have a size of more than $100 \mathrm{~nm}$. That refers to the range of vessels, fibers, and vessel pits. For THM woods from CR50 to CR70, the volume of the pore ranging from 10 to $1000 \mathrm{~nm}$ occupied the main part. For THM wood with CR75, the volume of 3-10-nm pores accounted for almost one half of total intrusion volume, which indicated that the amount of the pores with diameter in the range of $3-10 \mathrm{~nm}$ increased due to the narrowing effect in wood fiber and vessel lumen due to THM process.

From the above analysis, it was obvious that the THM process resulted in a significant pore structure change. The THM process altered the diameter of the vessels and fibers remarkably and caused a considerable decrease of the pore volume and pore area as illustrated in Table 4 and Fig. 2. The pores with diameters of $1-400 \mu \mathrm{m}$ reduced or even disappeared in THM woods. The pore size distribution shifted from the macropores to the mesopores and micropores after THM process. It is confirmed by SEM analysis that these microstructural changes were present in the vessels, fiber cells, and wood rays. The cell wall of the vessels and fiber cells shrunk and the lumen narrowed severely due to the THM treatment. The pore characteristics of THM wood with CR75 showed that microcapillaries were created in cell walls, which made up the remaining minor pores and cracks. The results are consistent with those reported previously [37].

\section{Bending properties}

The average values and standard deviations of bending properties for the untreated wood and THM woods are shown in Fig. 4. The analysis of variance of the 3-point bending test results determined that the THM process significantly increased the MOR and MOE of the THM wood in comparison with those of untreated wood, indicating that the THM process had successfully enhanced the mechanical property of poplar wood. Figure 4 also demonstrates the mean bending strengths of THM wood increased significantly with the increasing CR. The results showed that the MOR and MOE of THM wood with CR75 increased by 96.11 and $130.46 \%$ compared with those of untreated wood, respectively.

Table 4 Coefficients of functions according to Eq. (4)

\begin{tabular}{lrl}
\hline Sample & $\ln a$ & $b$ \\
\hline Untreated & -2.00 & 1.06 \\
THM wood & 0.447 & 0.84 \\
\hline
\end{tabular}

Only coefficients that were significant at the $5 \%$ level were included

THM thermo-hydro-mechanical

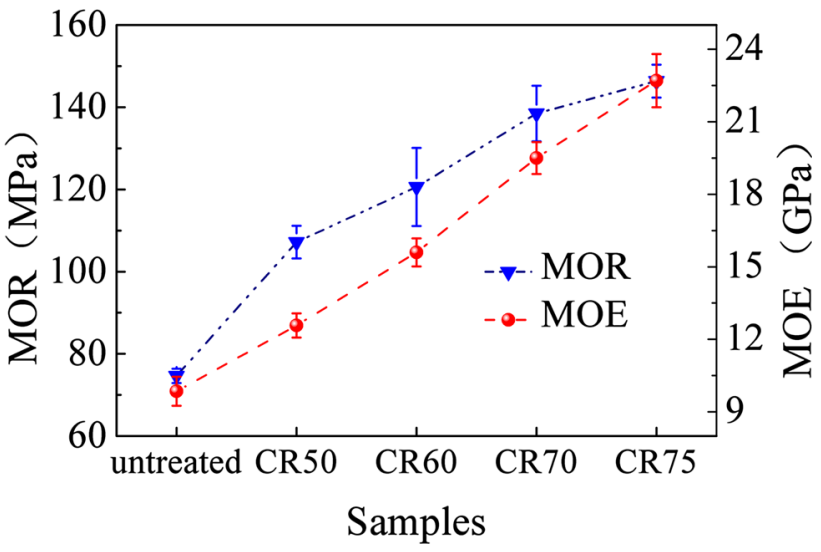

Fig. 4 Mechanical properties in static bending test for THM woods compared with untreated wood (MOR modulus of rupture, $M O E$ modulus of elasticity)

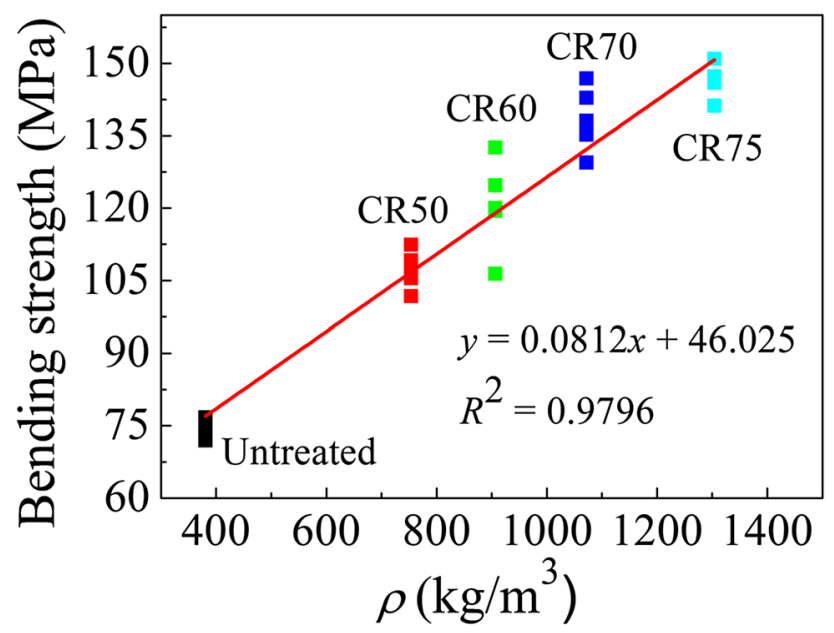

Fig. 5 Correlation between bending strength and density for untreated wood and THM woods

These results were attributed to the densification of the cells during the THM process. Higher CR always leads to higher density. It is more likely to increase the strength by increasing the density of wood materials [38]. It was noted that an increase in wood density was approximately proportional to increase in wood strength for wood processed with the THM (see Fig. 5 in the next section). It can also be observed that the increasing ratio in MOR from CR70 to CR75 was less than that from CR60 to CR70. This phenomenon indicated that extremely high CR may bring the risk of damage wood in structure because of high cell deformation and consequently the loss in strength (Fig. 2e). Some studies had mentioned a relationship between strength losses of wood and polymer degradation due to different factors. It was reported by Curling et al. that the losses in bending property were highly associated with the types of carbohydrate being degraded: MOR loss corresponds to loss in hemicelluloses, whereas MOE to 
decomposition of cellulose [39]. According to the results shown in Fig. 4, it can be inferred that polymer degradation did not happen at a level sufficient to impart negative effect on the flexural properties for the THM woods.

\section{Mathematical relation between density and bending strength}

As discussed above, the bending property was proportionate to the CR and the density of THM wood. The coefficients of the functions describing the relationship between strength (MOR) and density according to Eq. (4) for untreated and THM wood are given in Table 4. The presented curve for the correlation between bending strength and density was basically linear $(b \approx 1)$. Comparing the untreated wood with THM woods, $b$ was not affected significantly by THM process (see Table 4). The strength of THM woods was linearly proportionate to density shown in Fig. 5. Therefore, the correlation between bending strength and density of the THM woods corresponded well with the assumptions that compressed wood acted as a fibrous composite in axial direction illustrated in other study [40].

Increases in density and strength as an effect of THM process is shown in Table 5. The ratio of the performance for THM woods with different CRs to that of untreated wood was calculated to quantify the influence of the THM process. The density index, $\rho_{\mathrm{t}} / \rho_{0}$, showed the increase in density, and the strength index, $m_{\mathrm{t}} / m_{0}$, showed the increase in strength. The ratio between $m_{\mathrm{t}} / m_{0}$ and $\rho_{\mathrm{t}} / \rho_{0}$ expressed the increase in strength per density, which is referred to as quality index, $M_{\mathrm{t}} / M_{0}$. Given the $b$ for the functions in Table 4 , the ratio $\frac{m_{\mathrm{t}} / m_{0}}{\left(\rho_{\mathrm{t}} / \rho_{0}\right)^{b}}=\frac{a_{\mathrm{t}}}{a_{0}}$, here called as strength potential index, shows that the strength of THM wood increases relatively to the increase in density expected for untreated wood. It can be seen from Table 5 that the density index $\left(\rho_{\mathrm{t}} / \rho_{0}\right)$ and strength index $\left(m_{\mathrm{t}} / m_{0}\right)$ increased with the increasing $\mathrm{CR}$, while the quality index $\left(M_{\mathrm{t}} / M_{0}\right)$ and strength potential index $\left(a_{t} / a_{0}\right)$ showed the opposite trends. As stated above, there were twofold effects brought by the THM process on the wood properties, improvement

Table 5 Ratios of density $(\rho)$, strength $(m), M=m / \rho$, and $a=m / \rho^{b}$ of THM (t) to those of untreated (0) wood bending strength $(b=0.84)$ for THM process

\begin{tabular}{lllll}
\hline Samples & $\rho_{\mathrm{t}} / \rho_{0}$ & $m_{\mathrm{t}} / m_{0}$ & $M_{\mathrm{t}} / M_{0}$ & $a_{\mathrm{t}} / a_{0}$ \\
\hline CR50 & 1.97 & 1.44 & 0.73 & 0.81 \\
CR60 & 2.37 & 1.62 & 0.68 & 0.79 \\
CR70 & 2.82 & 1.86 & 0.66 & 0.77 \\
CR75 & 3.42 & 1.96 & 0.57 & 0.70 \\
\hline
\end{tabular}

THM thermo-hydro-mechanical, $C R$ compression ratio of density and possible destruction of cell walls. $a_{\mathrm{t}} / a_{0}$ is a measure of the latter effect. The $a_{\mathrm{t}} / a_{0}$ in Table 5 was below 1 , which indicated that THM process had some negative effect on bending strength and the cell walls were not much negatively affected by THM process.

\section{Set recovery (SR) and water absorption (WA)}

As could be seen in Fig. 6, the SR decreased with increasing CR. The result indicated that the higher the CR, the lower the shape recovery after water soaking for THM woods. The biggest difference in SRs happened between THM wood with CR60 and with CR70, where the former had 3 times greater SR than that of the latter. The THM wood with the highest CR of $75 \%$ presented the lowest SR value $(12.30 \%)$ in all the samples, which reached a value that was lower than that of the sample with CR50 by at least $70 \%$. It must be noted that no sample reached $100 \%$ recovery in this experiment, which signified that a certain structural change was irreversible and permanent possibly due to cell wall deformation (shown in Fig. 2e), stick-slip phenomenon or other reaction of wood components during compression, such as the thermal degradation and crosslinkage between the cell wall components [41, 42]. It has been reported that the elastic-strain energy stored in the semicrystalline microfibrils and lignin of wood is the main cause of SR [43, 44]. During the THM process, hemicelluloses hydrolysis under moisture and temperature weakened the connection between microfibrils and lignin and, therefore, allowed internal stresses to relax [45]. Significant reduction in SR for the THM wood with high CR can be explained by a breakdown of the cross-links responsible for the memory effect in wood, coupled with softening of lignin and perhaps the reformation of covalent bonds in the deformed position between the contacted components after the pre-steaming [46]. Furthermore, hydrothermal treatment could cause the chain scission of hemicelluloses

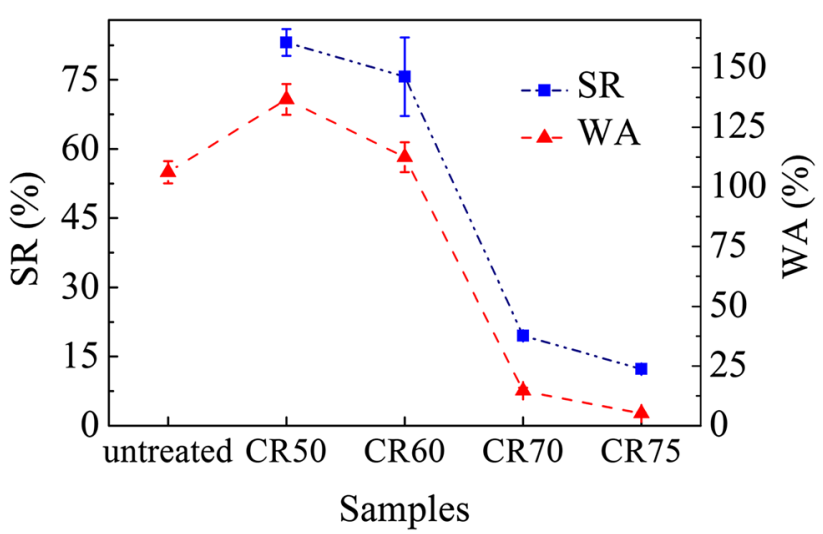

Fig. 6 Set recovery (SR) and water absorption (WA) of THM wood samples 
accompanied by slight cleavage of lignin [47], which may release the internal stresses to spring back. In a word, the conditions of THM process can influence the buildup of residual internal stresses, stress relaxation, thermal decomposition, and development of chemical bonds in the cell wall. The most stability of compressive deformation can be achieved with sufficient treatment pressure and time, which led to the CR higher than $70 \%$.

The effect of THM process on WA can also be clearly seen in Fig. 6. The feature of changes in WA was similar to that of SR. The WA reduced as the CR increased. The WAs of THM woods with CR of 50 and $60 \%$ were higher than that of untreated wood. This might be due to the spring back of wood cell at those compressed ratios. The lowest WA was also obtained by CR75, reaching the value of $5.09 \%$.

It was well known that wood generally contains water in three forms: free liquid water partially or completely filling the cell lumen or cavities between cells (free water), water vapor in the empty cavity spaces of cell wall which physically connected with cell wall with hydrogen bond (connected water), and water chemically connected with components of cell wall which is in small amount of 1-2\% (chemical water). The modification of free water and chemical water does not contribute to the changes in wood dimension. The dimensional change is only related to the connected water.

The moisture content (MC) refers to the total MC in the wood sample, which can be obtained from the following equation:

$\operatorname{MC}(\%)=\frac{W_{\mathrm{i}}-W_{0}}{W_{0}} \times 100$.

The fiber saturation point (FSP) of wood is the MC at which the cavities in cell lumen and between cells contained no free water, but the cell walls were fully saturated with connected water. The FSP depends on the amount of free hydroxyl groups in wood. When the MC is smaller than FSP, wood dimension changes with MC changing. While the MC is over FSP, wood dimension does not change anymore.

The WA of wood is a different concept with MC in this paper. The WA was the amount of increased water during the recovery compared to the compressed samples at equilibrium MC state according to Eq. (6) in the manuscript. In Eq. (6), $W_{\mathrm{i}}$ is weight after immersion in water for $390 \mathrm{~min}$, and $W_{\mathrm{e}}$ is weight of sample with moisture equilibrium before immersion in water $(\mathrm{g})$.

The samples were treated in the environment of $20^{\circ} \mathrm{C}$ and $65 \%$ relative humidity before water soaking test. Therefore, the samples were kept in an equilibrium MC state, which the cell walls and cell well cavities already contained liquid water.
Thus, the MC of THM wood is the sum of water absorption and equilibrium MC. Take CR75 as example, its WA value is $5.09 \%$, and the equilibrium $\mathrm{MC}$ for THM wood is about $10 \%$. Therefore, the MC of CR75 after water soaking test can be calculated to be $15 \%$. This implies the FSP of CR75 wood is less than $15.09 \%$, which is less than normal FSP value for untreated wood. The WA results showed reduction in FSP for THM wood with CR higher than 70 but not for those with CR lower than 70 in this study.

The decrease of WA or FSP of THM wood with CR higher than 70 is mainly caused by two aspects: (1) when the poplar wood was compressed during the THM process, the cell lumen was densified. The porosity of the CR75 was only $5.00 \%$. After the water soaking test of $420 \mathrm{~min}$, the values of the width and thickness swellings of CR75 were only 0.98 and $5.31 \%$, respectively. Therefore, the porosity of the CR75 remained small, which indicated only small change in the amount of free water occurred. (2) THM process with high pressure and longtime resulted in a series of chemical reactions in different components in wood surface, such as degradation of hemicelluloses, condensation of lignin and decomposition of extractives. The modifications of wood polysaccharide components due to high temperature led to lower WA in wood had been confirmed by Hakkou et al. [48] and Boonstra et al. [49]. The modifications of wood polysaccharide components due to high temperature can lead to lower WA in wood [48]. The availability and/or accessibility of the free hydroxyl groups of wood carbohydrates also plays an important role in the process of WA [49].

However, the CR50 and CR60 THM samples have higher WA comparing to those of untreated wood. In other words, the FSP of wood with low CR is not effectively reduced by THM process and the THM wood showed even greater FSP or volumetric swelling than unmodified wood did, which agreed with the results in the literature [50, 51]. This indicated there was less or no cross-linking chemical reaction happening when the CR was less than $70 \%$; consequently, it did not improve dimensional stability. It implied that the chemical reaction during THM process was attributed to not only high temperature but also high pressure and longer time. Extremely high pressure blocked the removal of free water from wood substrate and high moisture of wood remained during THM process. The high moisture catalyzed the carbonization reaction. Long treatment time at high pressure and temperature also enhanced the chemical reaction and resulted in lower WA and higher dimensional stability.

The WA test samples were cut to the size of $20 \mathrm{~mm} \times 20 \mathrm{~mm} \times$ sample thickness. The length of WA test samples was not $250 \mathrm{~mm}$, but was $20 \mathrm{~mm}$. The soaking time in water was 420 min including $30 \mathrm{~min}$ of vacuum 
immersion, $360 \mathrm{~min}$ of atmospheric immersion and $30 \mathrm{~min}$ of boiling water immersion. This method was based on the method used in the previous studies [46, 52]. Considering the CRs of our samples are above 50, the WA testing time in the present study was 120 min more than that in the references, which was $270 \mathrm{~min}$. Therefore, the soaking time in this study is enough to saturate all the compressed wood samples. To confirm this, the additional experiments of WA within 630 min were added and the WA with increasing time was recorded and is plotted in Fig. 7.

Figure 7 shows that the WA of samples remained constant for all the samples in this study when water immersion time was longer than $390 \mathrm{~min}$. Therefore, it can be confirmed that the water immersion time of 390 min was enough to saturate the wood samples. When the immersion time was less than $90 \mathrm{~min}$, the changes of WA were more pronounced. The WA of THM wood with CR50 increased from $124.19 \%$ for $90 \mathrm{~min}$ to $133.93 \%$ after $390 \mathrm{~min}$ of atmospheric immersion. The WA of THM wood with CR75 showed the smallest change. The WA of THM wood with CR75 increased from $4.73 \%$ to $5.23 \%$ at $390 \mathrm{~min}$ of atmospheric immersion. From Fig. 7, a negative correlation between the CR and the data of WA can be observed.

Liquid permeability is estimated based on the pore diameter of a porous material. Liquid penetrates the wood substance in three ways: water liquid flows into cell lumen by capillarity; water vapor diffuses into cell lumen; and bound water diffuses and reacts with the components in cell wall [53]. The vessels and fibers of wood were the features that were for liquid conduction in vertical direction. The constricted diameter of the pore and the pore distribution determine the efficiency of fluid flow in a porous material. As discussed in the section of the pore characteristic of THM wood, the pore size distribution shifted from the level of macropores to mesopores and

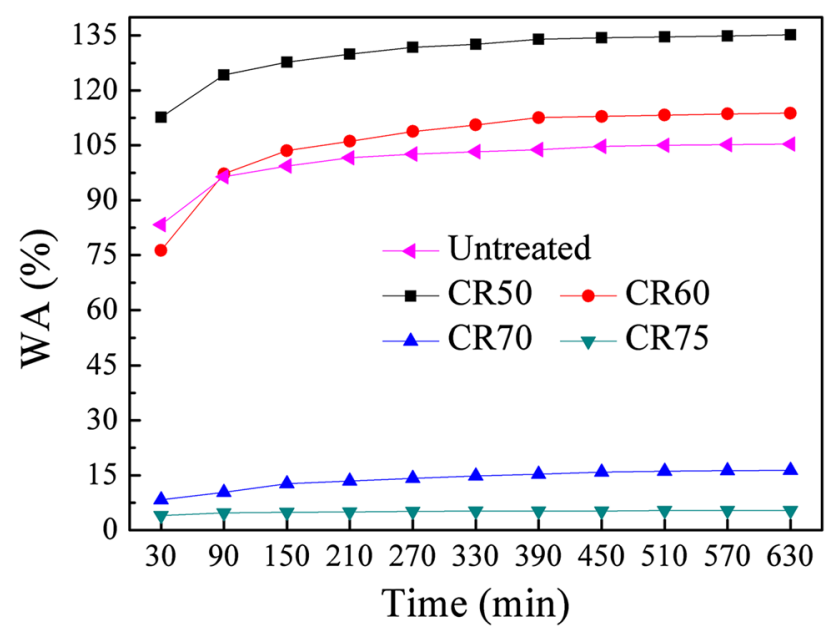

Fig. 7 Water absorption at increasing water soaking time for THM wood samples micropores after THM process. The higher CR, i.e., smaller porosity disappeared and narrowed of the most pores of the vessels and fibers, allowed harder entrance of liquid into cell wall, which consequently decreased wood WA. Furthermore, the chemical changes during THM process can affect the absorption of bound water.

\section{Dimensional stability}

Figure 8a, b shows the variation of width (WS) and thickness swelling (TS) during the water soaking test. After the water soaking, both in saturation and oven-dry condition, WS decreased substantially with the increase of CR. WS in saturation condition was higher than that in ovendry condition for the same sample as shown in Fig. 8a. In oven-dry condition, WS of THM wood with CR50 was slightly higher than that of untreated wood. However, WS of all other THM woods was smaller than that of untreated wood for both conditions, especially in saturation condition. WS of THM wood with CR75 reached the smallest values for both conditions, $0.98 \%$ for saturation condition and $0.71 \%$ for oven-dry condition, respectively. The WS had a statistically significant and positive linear correlation with WA. Their correlation coefficients were obtained and are presented in Fig. 8c.

The TS of THM woods represented the total swelling originated from the swelling of wood cell wall plus the swelling caused by the compressive stress release, which were present in wood due to THM treatment. Boiling water appeared to be more efficient or faster to induce the TS for THM woods than untreated wood. TS of THM woods in oven-dry condition was higher than that in saturation condition for the THM wood with the same CR (as shown in Fig. 8b), which was different with the features of WS. In oven-dry condition, TS of CR60 wood was higher than that of CR50 wood. This is because the recovery of thickness of CR60 was slightly smaller than that of CR50 (see Fig. 6), while the thickness of CR60 after compression was much smaller than that of CR50. When the CR was below $60 \%$, TS was higher than CR, indicating that THM woods swelled more than compression. Nevertheless, when the CR was above $60 \%$, TS was significantly lower than CR indicating that THM wood did not lose their compressed shape and did not increase the thickness after water soaking test. Compressive stress release caused a swelling in the wood, which is a dimensional stability problem for THM wood. However, this problem became smaller when CR increased up to $70 \%$. It could be seen from Fig. 8d that TS has positive correlation with WA.

It is well known that under the effect of heat, moisture, and pressure, polysaccharides, especially the hemicelluloses, are hydrolyzed to some extent. It is assumed that during the THM treatment, especially during the treating 

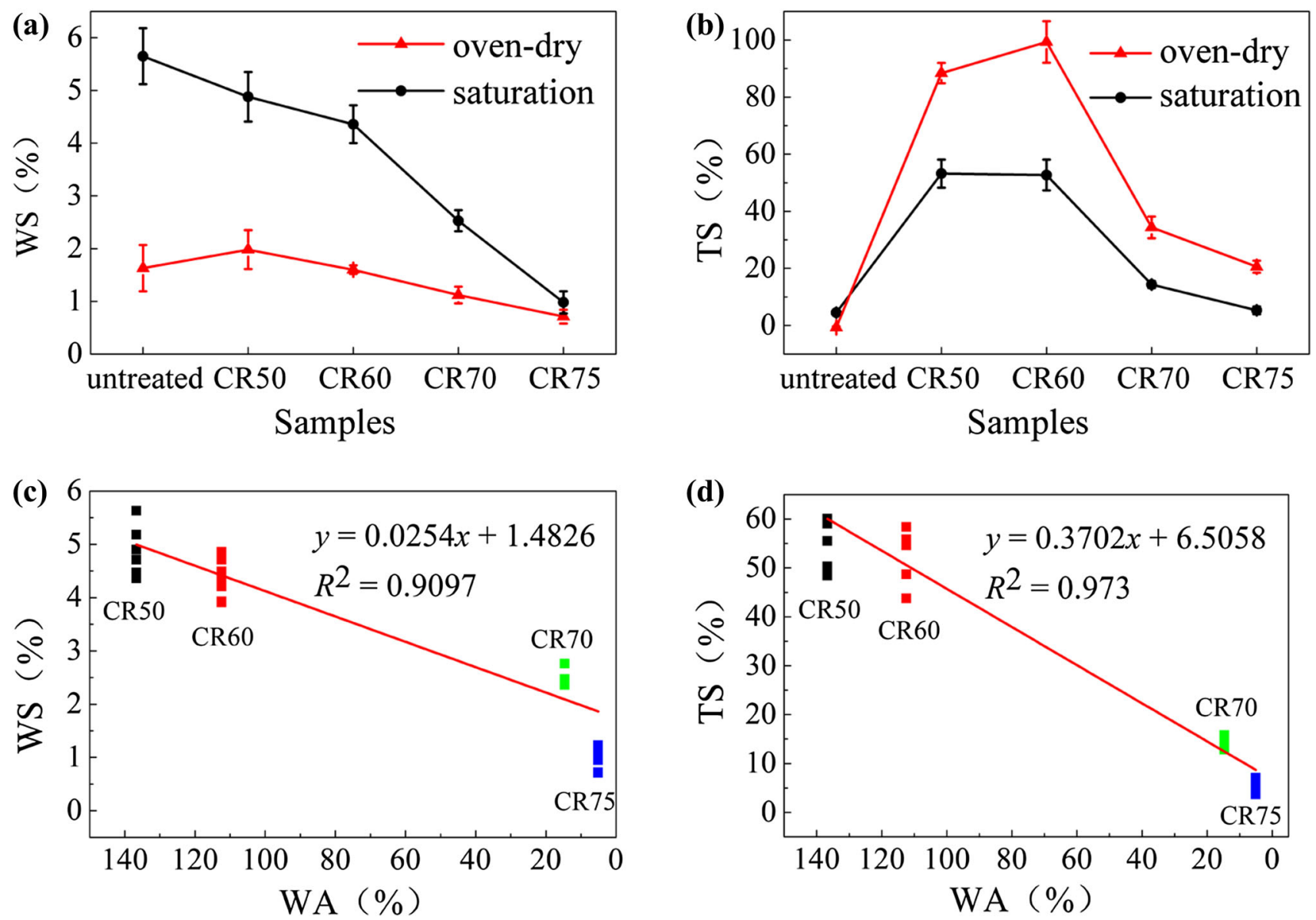

Fig. 8 Dimensional swelling of THM woods. a Width swelling (WS), b thickness swelling (TS), c linear relations between the WS (saturation) and water absorption (WA), and d linear relations between the TS (saturation) and WA

stage of $T_{2}-T_{3}$ shown in Fig. 1, when the platens closed and remained in the same position, the hydrolysis and elution of hemicelluloses allowed the cellulose to move, thereby weakening or breaking the linkage between microfibrils and lignin. Therefore, the stresses in the microfibrils and matrix were relaxed to different extents, depending on the treatment conditions, such as duration, pressure, and temperature [9]. Furthermore, the degradation of hemicelluloses at high temperatures can lead to stress relaxation and reduction in hygroscopicity in THM specimens. Therefore, the structural fractures and the chemical degradation in cell walls both caused the reduction in the swelling of dimension.

\section{Microstructure after water soaking}

Previous analysis had shown the WA and dimension expansion of THM woods after water soaking cycle. Figure 9 shows the recovery of compressive deformation of THM woods after water soaking. Figure $9 a, b$ shows that wood cells with a low CR mainly possessed elastic deformation and almost resumed their original shape after the water soaking cycle. During THM process, fiber cells underwent deformation and their microfibrils were subjected to internal stress. After soaking tests, when the physico-chemical bonds were weakened, the internal stresses forced those microfibrils to return to their initial form. Obviously, this phenomenon depended on the distribution of the inner stress in the cells. The woods with CR under $60 \%$ showed the high structural recovery resulting in almost set recovery. There were cracks present in the fiber cells of CR50 and CR60 (see arrows in Fig. 9a, b) after soaking test; however, no fractures were found in these compressed samples. This indicated that soaking test may bring a negative effect on the structural integrity during shape recovery. The degradation may also be due to the compression during THM process.

As can be seen from Fig. 9c, d, the THM woods above with CR70 and CR75 showed considerably lower structural recovery rate. The cell structure did not recover and left distorted indicating that a certain amount of irrecoverable deformation occurred in the cell wall structure during the THM process. Not only thick-walled cells, e.g., wood fibers, but also thin-walled cells were permanently 
Fig. 9 SEM images $(\times 2000)$ on transverse surface of recovered THM wood after water soaking: a CR50, b CR60, c CR70, and d CR75. The fractures in the fiber cell walls are shown with white arrows
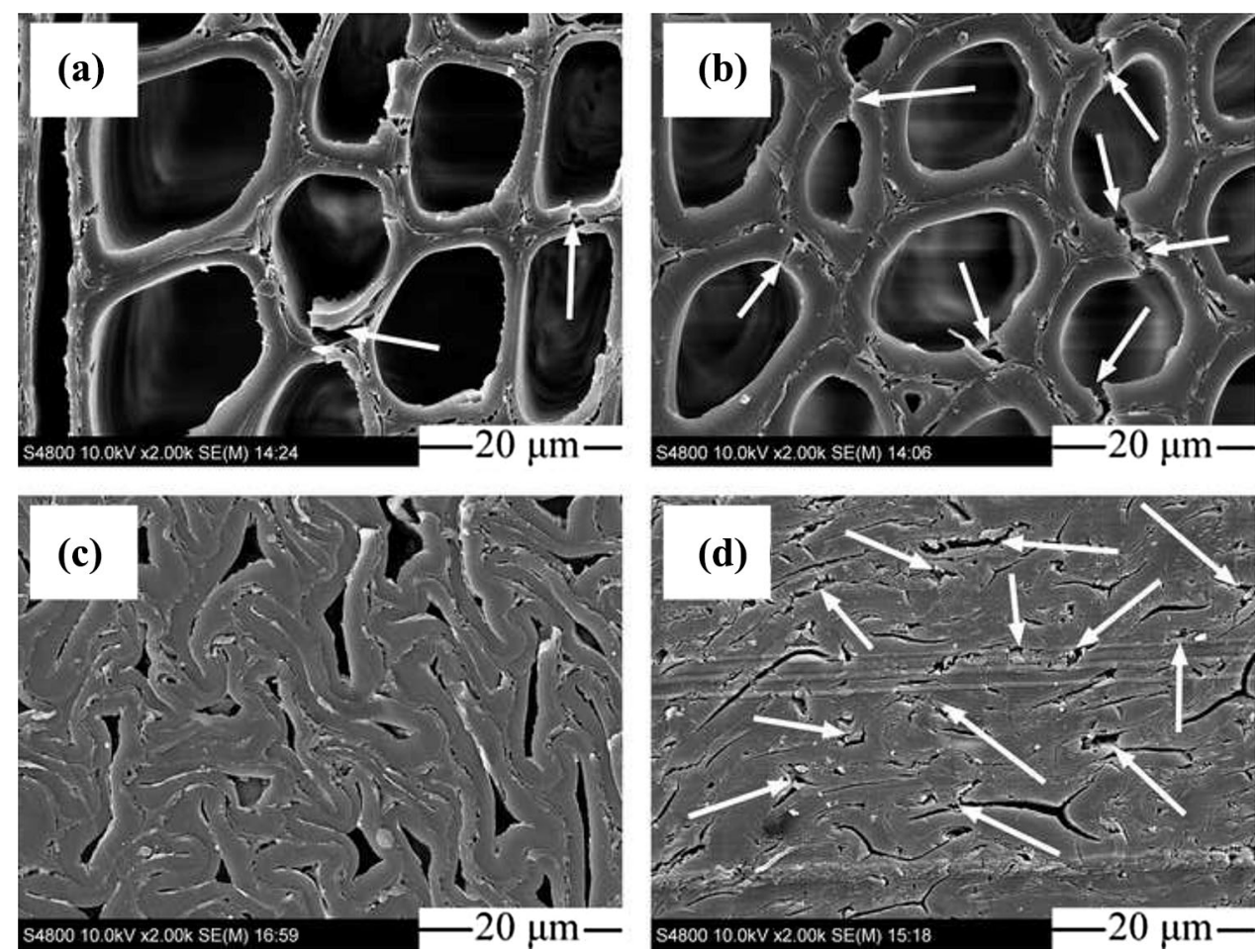

deformed on compression. One reason was that plastic or viscoelastic deformation phenomenon may occur during the THM process causing permanent flow of the cell wall constituents, such as the "stick-slip" phenomenon [54]. Another reason corresponded to microcracks that arose on the cell wall structure (shown in Figs. 2e, 9d). Therefore, crack was an indicator of the degree of cell wall compression during the THM process. Moisture-induced shape recovery was inversely proportional to the degree of $\mathrm{CR}$. Structures with high remaining deformation most likely had suffered some damage and were more plastically deformed on compression, which consequently affects the shape recovery [55]. Therefore, one indicator of the nondestructive character of the THM process was the high degree of shape recovery after soaking in water.

During the THM process, under the combined effect of moisture $(25 \%$ relative humidity), high temperature $\left(160{ }^{\circ} \mathrm{C}\right)$, and high pressure $(4-12 \mathrm{MPa})$, all of the wood polymers, except the crystalline part of cellulose, became elastic and can undergo large deformation. Cellulose macromolecules stored elastic energy because of their semicrystalline nature. When wood was compressed, each microfibril helix was deformed. Thus, the macromolecules of the crystalline regions of the microfibrils were elastically deformed. The elastic energy stored in these regions was considered the main cause of the shape-memory effect in THM wood. These regions could also undergo plastic deformation, as it was for any crystalline material, if very high pressure were applied. THM woods with CR above
$70 \%$ could not recover well from a compressed state, which showed that plastic deformation occurred during the THM process. Although the main mechanism controlling the shape memory of THM wood was the elastic-strain energy stored in the helical semicrystalline microfibrils, the thermo-hydro-plastic behavior of lignin under wet and relatively high temperature conditions may also contribute. Moreover, strong bonding exists between the three main components. If the interconnection system between cellulose, hemicelluloses, and lignin was not broken during the THM process, the compression set in THM wood will be metastable and will return to its initial shape with the condition of heating and rewetting. However, THM woods above CR70 broke these bonds and kept the microfibrils from relaxing the internal stresses and create new bonds. In a word, the elastic-strain energy can be released by the function of temperature, moisture, and pressure at certain duration. From this study, the fractures of cell walls, degradation of hemicelluloses, and condensation of lignin were formed during the THM process when CR reached a high value. Therefore, the most deformation of THM woods with CR above $70 \%$ was kept as permanent.

\section{Conclusion}

The results of this study showed that THM process of poplar wood caused changes in microstructure, porosity, as well as in its mechanical properties and dimensional 
stability. The cell lumen volume reduced and the cells deformed presenting micro-fractures in the cell walls with increasing CR due to THM process. The fiber cells were the main structures affected mostly by the THM process. The cell structure did not completely recover but remained as being distorted after water soaking, indicating that a certain amount of irrecoverable deformation occurred in the cell wall structure during THM process. Consequently, permanent micro-fractures formed in cell wall components due to compression. The MIP analysis showed that the THM process altered the diameter of wood cells significantly and caused a considerable decrease of the total pore volume and pore area. The proportion of pores with macrodiameters decreased or even disappeared. The pore size distribution shifted from the macropores to the mesopores and micropores after THM process. The increases in MOR and MOE were approximately proportional to the increases in CR. The increase of bending property can be attributed to the combination of the complete closure of vessels and the partly collapsing of fiber with the high level of compression. The ST of THM woods decreased dramatically and dimensional stability increased with the increasing CR. Less than 5\% recovery was obtained for THM wood with CR75. The TS and WS were much lower for THM wood with higher CR. The combination of high temperature, moisture, and mechanical action during THM process could create a novel material with improved mechanical property and increased dimensional stability. There is potential to transfer efficiently the THM process from laboratory processing to industrial scale.

Acknowledgements The authors appreciate the financial support from the National Nonprofit Institute Research Grant of CAFINT (CAFYBB2017ZX003).

\section{References}

1. State Forestry Administration of China (2014) Statistical yearbook of forestry. China Forestry Publishing House, Beijing

2. Bektas I, Guler C, Kalaycioğlu H, Mengeloglu F, Nacar M (2005) The manufacture of particleboards using sunflower stalks (Helianthus annuus L.) and poplar wood (Populus alba L.). J Compos Mater 39:467-473

3. Burdurlu E, Kilic M, Ilce AC, Uzunkavak O (2007) The effects of ply organization and loading direction on bending strength and modulus of elasticity in laminated veneer lumber (LVL) obtained from beech (Fagus orientalis L.) and lombardy poplar (Populus nigra L.). Constr Build Mater 21:1720-1725

4. Bao M, Huang X, Zhang Y, Yu W, Yu Y (2016) Effect of density on the hygroscopicity and surface characteristics of hybrid poplar compreg. J Wood Sci 62:441-451

5. He M, Zhang J, Li Z, Li M (2016) Production and mechanical performance of scrimber composite manufactured from poplar wood for structural applications. J Wood Sci 62:429-440

6. Welzbacher CR, Wehsener J, Rapp AO, Haller P (2007) Thermomechanical densification combined with thermal modification of
Norway spruce (Picea abies Karst) in industrial scale-dimensional stability and durability aspects. Holz Roh-Werkst 66:39-49

7. Kutnar A, Kamke FA, Nairn JA, Sernek M (2008) Mode II fracture behavior of bonded viscoelastic thermal compressed wood. Wood Fiber Sci 40:362-373

8. Shams MI, Yano H (2010) Compressive deformation of phenol formaldehyde (PF) resin-impregnated wood related to the molecular weight of resin. Wood Sci Technol 45:73-81

9. Navi P, Heger F (2004) Combined densification and thermo-hydro-mechanical processing of wood. MRS Bull 29:332-336

10. Sandberg D, Haller P, Navi P (2013) Thermo-hydro and thermohydro-mechanical wood processing: an opportunity for future environmentally friendly wood products. Wood Mater Sci Eng 8:64-88

11. Huang X, Kocaefe D, Kocaefe Y, Boluk Y, Pichette A (2012) Study of the degradation behavior of heat-treated jack pine (Pinus banksiana) under artificial sunlight irradiation. Polym Degrad Stab 97:1197-1214

12. Metsä-Kortelainen S, Antikainen T, Viitaniemi P (2005) The water absorption of sapwood and heartwood of Scots pine and Norway spruce heat-treated at $170{ }^{\circ} \mathrm{C}, 190{ }^{\circ} \mathrm{C}, 210^{\circ} \mathrm{C}$ and $230{ }^{\circ} \mathrm{C}$. Holz Roh-Werkst 64:192-197

13. Esteves B, Marques AV, Domingos I, Pereira H (2006) Influence of steam heating on the properties of pine (Pinus pinaster) and eucalypt (Eucalyptus globulus) wood. Wood Sci Technol 41:193-207

14. Fang C, Mariotti N, Cloutier A, Koubaa A, Blanchet P (2011) Densification of wood veneers by compression combined with heat and steam. Eur J Wood Wood Prod 70:155-163

15. Kutnar A, Kamke FA, Sernek M (2008) Density profile and morphology of viscoelastic thermal compressed wood. Wood Sci Technol 43:57-68

16. Todaro L, Zanuttini R, Scopa A, Moretti N (2012) Influence of combined hydro-thermal treatments on selected properties of Turkey oak (Quercus cerris L.) wood. Wood Sci Technol 46:563-578

17. Lesar B, Humar M, Kamke FA, Kutnar A (2013) Influence of the thermo-hydro-mechanical treatments of wood on the performance against wood-degrading fungi. Wood Sci Technol 47:977-992

18. Kutnar A, Humar M, Kamke FA, Sernek M (2011) Fungal decay of viscoelastic thermal compressed (VTC) wood. Eur J Wood Wood Prod 69:325-328

19. Lowell S, Shields JE, Thomas MA, Thommes M (2004) Characterization of porous solids and powders: surface area, pore size and density. Springer, The Netherlands, pp 189-212

20. Plötze M, Niemz P (2010) Porosity and pore size distribution of different wood types as determined by mercury intrusion porosimetry. Eur J Wood Wood Prod 69:649-657

21. Hacke UG, Sperry JS, Pockman WT, Davis SD, McCulloh KA (2001) Trends in wood density and structure are linked to prevention of xylem implosion by negative pressure. Oecologia 126:457-461

22. GB/T 1736.1 (2009) Method of testing in bending strength of wood. Standard Administration of China, Beijing

23. Gibson LJ, Ashby MF (1997) Cellular solids: structure and properties. Cambridge University Press, Cambridge, pp 307-308

24. Dinwoodie JM (2000) Timber: its nature and behavior. CRC Press, New York

25. Bodig J, Jayne BA (1982) Mechanics of wood and wood composities. Krieger Pub, New York

26. Blomberg J, Persson B, Blomberg A (2005) Effects of semiisostatic densification of wood on the variation in strength properties with density. Wood Sci Technol 39:339-350

27. GB/T 1736.2 (2009) Method for determination of the swelling of wood. Standard Administration of China, Beijing 
28. Bekhta P, Proszyk S, Krystofiak T, Sedliacik J, Novak I, Mamonova M (2015) Effects of short-term thermomechanical densification on the structure and properties of wood veneers. Wood Mater Sci Eng 2015:1-15

29. Standfest G, Kutnar A, Plank B, Petutschnigg A, Kamke FA, Dunky M (2013) Microstructure of viscoelastic thermal compressed (VTC) wood using computed microtomography. Wood Sci Technol 47:121-139

30. Zauer M, Pfriem A, Wagenführ A (2013) Toward improved understanding of the cell-wall density and porosity of wood determined by gas pycnometry. Wood Sci Technol 47:1197-1211

31. Sing KS (1985) Reporting physisorption data for gas/solid systems with special reference to the determination of surface area and porosity (recommendations 1984). Pure Appl Chem 57:603-619

32. Sawabe O, Mori K, Takeuchi T (1973) Micro-pore structure in cell wall of wood. Mokuzai Gakkaishi 19:55-62

33. Stone J, Scallan A (1965) Effect of component removal upon the porous structure of the cell wall of wood. J Polym Sci Part C Polym Symp 11:13-25

34. Nakatani T, Ishimaru Y, Iida I, Furuta Y (2008) Micropore structure of wood: change in micropore structure accompanied by delignification. J Wood Sci 54:252-255

35. Kojiro K, Miki T, Sugimoto H, Nakajima M, Kanayama K (2010) Micropores and mesopores in the cell wall of dry wood. J Wood Sci 56:107-111

36. Zauer M, Kretzschmar J, Großmann L, Pfriem A, Wagenführ A (2013) Analysis of the pore-size distribution and fiber saturation point of native and thermally modified wood using differential scanning calorimetry. Wood Sci Technol 48:177-193

37. Scholz G, Zauer M, Van den Bulcke J, Van Loo D, Pfriem A, Van Acker J, Militz H (2010) Investigation on wax-impregnated wood. Part 2: study of void spaces filled with air by He pycnometry, $\mathrm{Hg}$ intrusion porosimetry, and 3D X-ray imaging. Holzforschung 64:587-593

38. O'Connor JP (2007) Improving wood strength and stiffness through viscoelastic thermal compression. MS thesis, Oregon State University, Corvallis, pp 56-68

39. Curling SF, Clausen CA, Winandy JE (2002) Relationships between mechanical properties, weight loss, and chemical composition of wood during incipient brown-rot decay. Forest Prod J 52:34-37

40. Ashby MF, Jones D (1999) Engineering materials 2: an introduction to microstructures, processing and design. Department of Engineering, Cambridge University, England, pp 12-13
41. Bekhta P, Proszyk S, Krystofiak T, Lis B (2015) Surface wettability of short-term thermo-mechanically densified wood veneers. Eur J Wood Wood Prod 73:415-417

42. Diouf PN, Stevanovic T, Cloutier A (2011) Effects of thermohygro-mechanical densification on the surface characteristics of trembling aspen and hybrid poplar wood veneers. Appl Surf Sci 257:3558-3564

43. Inoue M, Hamaguchi T, Morooka T, Higashihara T, Norimoto M, Tsunoda T (2000) Fixation of compressive deformation of wood by wet heating under atmospheric pressure. Mokuzai Gakkaishi 46:298-304

44. Navi P, Heger F (2004) Combined densification and thermo-hydro-mechanical processing of wood. MRS Bull 29:332-336

45. Liu H, Shang J, Chen X, Kamke FA, Guo K (2013) The influence of thermal-hydro-mechanical processing on chemical characterization of Tsuga heterophylla. Wood Sci Technol 48:373-392

46. Inoue M, Norimoto M (2008) Fixation of compressive deformation in wood by pre-steaming. J Trop For Sci 20:273-281

47. Dwianto W, Morooka T, Norimoto M, Kitajima T (2005) Stress relaxation of sugi (Cryptomeria japonica $\mathrm{D}$. Don) wood in radial compression under high temperature steam. Holzforschung 53:541-546

48. Hakkou M, Pétrissans M, Zoulalian A, Gérardin P (2005) Investigation of wood wettability changes during heat treatment on the basis of chemical analysis. Polym Degrad Stab 89:1-5

49. Boonstra MJ, Acker J, Kegel E, Stevens M (2006) Optimisation of a two-stage heat treatment process: durability aspects. Wood Sci Technol 41:31-57

50. Rautkari L, Hill CA (2014) Effect of initial moisture content on the anti-swelling efficiency of thermally modified Scots pine sapwood treated in a high-pressure reactor under saturated steam. Holzforschung 68:323-326

51. Obataya E, Higashihara T, Tomita B (2002) Hygroscopicity of heat-treated wood III. Effect of steaming on the hygroscopicity of wood. Mokuzai Gakkaishi 48:348-355

52. Inoue M, Norimoto M, Tanahashi M, Rowell RM (2007) Steam or heat fixation of compressed wood. Wood Fiber Sci 25:224-235

53. Banks W (1973) Water uptake by scots pine sapwood, and its restriction by the use of water repellents. Wood Sci Technol $7: 271-284$

54. Keckes J, Burgert I, Frühmann K, Müller M, Kölln K, Hamilton M (2003) Cell-wall recovery after irreversible deformation of wood. Nat Mater 2:810-813

55. Ellis S, Steiner P (2002) The behaviour of five wood species in compression. Iawa J 23:201-211 